\title{
Development of an Artificial Breeding and Hatchery Technique for Exotic Ornamental Fish Sahyadria denisonii (Day, 1865)
}

\author{
A.M.A.N. Adikari", U. Edirisinghe ${ }^{1}$, E.D.M. Epasinghe, H.M.P. Kithsiri, \\ V. Phalawathtaarachchi and T.A.D.W. Karunarathne \\ National Aquatic Resources Research and Development Agency (NARA) \\ Crow Island \\ Colombo-15 \\ Sri Lanka
}

\begin{abstract}
Sahyadria denisonii is one of the highly demanded exotic ornamental fish species. Development of artificial breeding technique for Sahyadria denisonii is important under local conditions. The captive breeding of this species did not occur under the environmental manipulation method used in the present study. However, breeding was successful, when Ovaprim hormone was injected at $0.5 \mathrm{ml}$ per $\mathrm{kg}$ of body weight of the female at $9 \mathrm{~h}$ latency period. Average number of eggs laid was $216 \pm 33$ and average egg size at maturity was $1.6 \pm 0.2 \mathrm{~mm}$. Duration of development of eggs to hatchling was $36 \mathrm{~h}$ from time of fertilization. Feeding Artemia nauplii as an initial feed resulted a significantly higher growth $(P<0.05)$ while micro-worm fed hatchlings exhibited significantly high survival rate. Therefore, results of this study revealed that a single dose of Ovaprim at $0.5 \mathrm{~mL} / \mathrm{kg}$ of $B W$ of females and half of that dose for males can be used for breeding of $\underline{S}$. denisonii. Artemia nauplii, and micro-worm larval feeds can be used as the starter feeds for $\underline{S}$.denisonii postlarvae.
\end{abstract}

Keywords: Captive breeding, environmental manipulation, hormonal manipulation, postlarval feed, $\underline{\text { S. denisonii }}$

\section{INTRODUCTION}

The art of breeding, rearing and maintenance of ornamental fish have developed into a modern business worldwide and it has become an important source of wealth and foreign exchange earning source for countries. Presently, the ornamental fish industry is a rapidly developing sector in Sri Lanka. This industry largely depends on more colourful and fancy exotic fish species. Export of ornamental fish from Sri Lanka not only comprises of production from Sri Lankan farms, but also includes some of other imported high valued and rare species. The world ornamental fish importers request such species in their shipments. Sri Lankan ornamental fish exporters also have to import such species from other countries to be competitive in the market chain and re-export these with their shipments. Sahyadria denissonii is one of the fish species regularly re-exports from Sri Lanka. This exotic Cyprinid, more popularly as Miss Kerala, has become one of the most popular exported ornamental fish species in the world (Sekharan and Ramachndran, 2006). S. denissonii is native species in India and occupy the first cluster of the most preferred species in the world

\footnotetext{
1 Department of Animal Science, Faculty of Agriculture, University of Peradeniya, Peradeniya, Sri Lanka

* Corresponding author: adikari.aman@gmail.com
} 
export market and considered a high-valued species (Mittal, 2009).This fish is being requested in all trade enquiries and had been exported in consistent numbers regularly (Sekharan and Ramachandran, 2006) from India. The main market for S. denisonii is Singapore $(48.63 \%)$, Hong Kong (30.52\%) and Malaysia (18.4\%), while low quantities being exported to Germany, United Kingdom and Japan (Raghavan et al., 2013). Export market of this species in India totally depends on wild collections and the supply is not up to the demand (Mercy et al., 2013a). Therefore, the value of this species still remain high and the cost of importing fry or juveniles to Sri Lanka and re-exporting them to other countries is costly. The captive breeding of $S$. denisonii was not successful in Sri Lanka until now. Hence, the objectives of this study were to develop a suitable captive breeding and larval rearing technologies for $S$. denisonii and thereby to reduce the imports of this species and save foreign exchange within the country by increasing exports.

\section{MATERIALS AND METHODS}

Fifty Juvenile fish 8-10 $\mathrm{cm}$ were obtained from a private ornamental fish importer in Sri Lanka. Experiments were conducted at the Ornamental Fish Unit in National Aquatic Resources Research and Development Agency. The fishes were kept in 2 ppm Methylen Blue and 2 ppt salt solution for five days for disinfection. The brood-stocks were reared in 3 m X 3 m X 3 m cement tanks with aquatic vegetation, wooden stumps and stones. Water depth was maintained at $90 \mathrm{~cm}$ and continuous aeration was provided. Fish were fed three times per day ad libitum using artificial (floating feed containing $42 \%$ crude protein) and live-feeds (Artemia naupli and Moina). The mature males were selected by checking the release of milt when the belly was pressed slightly. Ovarian biopsies were carried out under the photomicroscope (3012 model) for each and every female fish to determine the maturity. Egg samples were taken using fine polyethylene tubes of $0.8 \mathrm{~mm}$ inner diameter and $1.0 \mathrm{~mm}$ outer diameter. Serra's solution (60\% Alchol: 30 Formalin: 10 Gleceric acid) was used to clean the eggs before examine. Female fishes that have nucleus centred eggs were selected for the experiment. Before ovarian biopsies and hormone administration, fishes were anaesthetised using Tricaine methane sulfonate anaesthetic bath at 50-100 ppm concentration. Selected male and female fishes were stocked separately in $3.0 \mathrm{~m} \mathrm{X} 3.0 \mathrm{~m} \mathrm{X}$ $3.0 \mathrm{~m}$ in cement tanks for four weeks at a stocking density of two individuals per $\mathrm{m}^{2}$. Fishes were fed with Artemia nauplii, Moina and vitamin E-enriched and minced ox-heart three times per day ad libitum. Each tank was provided with conditioned water and an aerator. As the spawning tanks, four glass tanks $(120 \mathrm{~cm} \mathrm{X} 60 \mathrm{~cm} \mathrm{X} 60 \mathrm{~cm})$ were used for hormoneinduced method and nine cement tanks $(160 \mathrm{~cm} \mathrm{X} 100 \mathrm{~cm} \mathrm{X} 50 \mathrm{~cm})$ were used for environmental manipulation method. The bottoms of the tanks were covered with aquarium gravels with a thickness of $5 \mathrm{~cm}$, and the tanks were filled with dechlorinated water to a total depth of $30 \mathrm{~cm}$ and allowed for a day to settle the particles. Subsequently, Lagenandra ovatas plants were paced at the bottom and aerated using an aquarium air blower.

Environmental manipulation methods and hormone-induced breeding methods were performed in breeding experiments. Environmental manipulation was carried out in indoor system, outdoor system and indoor system with water flows. Selected mature male and female fishes were introduced into each system at 1:1 male to female ratio and allowed to breed. Spawning performances such as courtship and presence of spawned eggs were observed. Environmental manipulation experiments were repeated five times at two-month intervals to increase the number of replicates. During the hormonal induce breeding experiments, synthetic gonadotrophin hormone Ovaprim (SGnRH+DomperidoneSyndellaboratory, Canada) and LHRHa were tested. Mature females (13-15 g weight range) 
were selected for induced breeding. Both female and male fish were given a single dose of hormone. Hypodermic syringes with a small size needle $(1.5 \mathrm{~cm}$ length) were used to inject hormone intra-muscularly. Ovaprim was available in liquid form and LHRHa was available in solid form and packed in bottles. Before injecting LHRHa, it was dissolved in $1 \mathrm{ml}$ sodium chloride $(0.9 \% \mathrm{w} / \mathrm{v})$. Similar concentration of Domperidon $(0.5 \mathrm{~mL} / \mathrm{kg})$ was also injected with LHRHa. Males were administered with half the dose prior to females and introduced into $120 \mathrm{~cm} \mathrm{X} 60 \mathrm{~cm} \mathrm{X} 60 \mathrm{~cm}$ glass tanks. Different concentrations were tested as treatments and each treatment was triplicated (Table I).

Table 1. Tested hormone concentrations

\begin{tabular}{cccccc}
\hline $\begin{array}{l}\text { Ovaprim }(\mathrm{mg} / \mathrm{kg} \text { of body } \\
\text { weight })\end{array}$ & \multicolumn{2}{c}{$\begin{array}{c}\text { LHRHa }(\mu \mathrm{g} / \mathrm{kg} \text { of body } \\
\text { weight })\end{array}$} & \multicolumn{2}{c}{$\begin{array}{c}\text { Domperidon }(\mathrm{mL} / \mathrm{kg} \text { of body } \\
\text { weight })\end{array}$} \\
\hline Female & Male & Female & Male & Female & Male \\
\hline 0.4 & 0.2 & 20 & 10 & 0.5 & 0.5 \\
0.5 & 0.25 & 30 & 15 & 0.5 & 0.5 \\
0.8 & 0.4 & 40 & 20 & 0.5 & 0.5 \\
\hline
\end{tabular}

It was observed that induced brood fish did not release ova or milt by their own. Nine hours after the administration of the hormone, hand stripping was carried out for both males and females. Released ova were collected into clean, dry petri-dishes. Milt of each male was made to fall on the ova by gently pressing the abdomen. Immediately, the milt was mixed gently by using a feather. The fertilized eggs were washed properly using the water in the breeding tank. The petri-dishes with fertilized eggs were incubated in $30 \mathrm{~cm}$ x $30 \mathrm{~cm}$ x 30 $\mathrm{cm}$ glass tanks. The water used for breeding was taken to incubate the eggs. Aeration was provided for each tank using an aerator.

Water quality parameters in each experiment set up were measured. Dissolved Oxygen and water temperature were measured with a DO meter (Pro ODO model) and $\mathrm{pH}$ was measured with a $\mathrm{pH}$ meter (pH6+ model). Ammonia concentration and hardness of water were measured using a spectrophotometer $(\mathrm{HACH})$. Water quality parameters in different treatments were compared using One-way ANOVA and the means were compared using Duncan's Multiple Range test at 95\% significance level.

A feeding experiment was conducted for 30 days to find out the suitable initial feed for $S$. denissoni. A batch of 180 uniform sized five-day old post-larvae having a mean length of 3 $\pm 0.02 \mathrm{~mm}$ and $0.04 \pm 0.5 \mathrm{mg}$ were randomly divided into nine indoor glass tanks $(30 \mathrm{~cm} \mathrm{X} 60$ $\mathrm{cm}$ X $30 \mathrm{~cm}$ ). Micro-worms, Artemia nauplii and Moina were tested ad libitum at three times per day. Weight and length gains were measured and specific growth rate corresponding to length (SGR-L) was found. Survival rate was expressed as a percentage of the number of fish introduced into each tank and number survived. Results of initial feed experiments, length gain, weight gain and SGR-L were compared using Two-way Analysis of Variance procedure at $95 \%$ significance level, using SAS package.

\section{RESULTS AND DISCUSSION}

Out of the two different captive breeding methods, spawning was observed only in hormone induced breeding method. Respect to the environmental manipulation methods, courtship behaviour could be observed only in tanks which did not possess flowing water at $90 \mathrm{~cm}$ 
water depth having a water temperature of $28.2 \pm 0.3$ and $\mathrm{pH} 6.4 \pm 0.2$. After introduction of fishes into indoor and outdoor tanks with aquatic vegetation, males and females exhibited active swimming movements and chasing behaviour (males chasing females) on the following day in the morning around $8.30 \mathrm{a} . \mathrm{m}$. But females did not release ova. Mercy et al., 2013 reported that $S$. denisonii apparently seeks quiet water for spawning similar to many of the other barb species. Therefore, it may be the reason for not observing the courtship behaviour in the treatments having flowing water. Raghavan et al. (2009), Manoj et al.(2010) and Mercy et al. (2013) reported that $S$. denisonii spawn at $\left(22-24{ }^{\circ} \mathrm{C}\right)$. However, the water temperature in the present study was $28.8 \pm 0.3{ }^{\circ} \mathrm{C}$ (Table 3 ), which could be the reason for the failure of environmental manipulation methods. Female fish with a mean egg diameter of $1.6 \pm 0.2 \mathrm{~mm}$ were used for induced breeding experiments (Table 2). S. denisonii, which received Ovaprim hormone at a concentration of $0.5 \mathrm{~mL} / \mathrm{kg}$ of body weight spawned. Spawning did not occur in any other treatment.

Table 2. Mature Lengths \& Weights and egg size of S. denisonii

\begin{tabular}{llc}
\hline & \multicolumn{1}{c}{ Parameter } & Mean \pm SD \\
\cline { 2 - 3 } Female & \multicolumn{1}{c}{ Total length at maturity $(\mathrm{cm})$} & $14.0 \pm 0.2$ \\
& Total weight at maturity $(\mathrm{g})$ & $13.4 \pm 1.6$ \\
\multirow{3}{*}{ Male } & Mean egg diameter $(\mathrm{mm})$ & $1.6 \pm 0.2$ \\
& Total length at maturity $(\mathrm{cm})$ & $15.1 \pm 1.0$ \\
& Total weight at maturity $(\mathrm{g})$ & $21.9 \pm 0.7$ \\
\hline
\end{tabular}

Nine hours after the injection, hand stripping was carried out. At this stage, ova came out freely from the female fishes that received Ovaprim hormone at a concentration of $0.5 \mathrm{~mL} / \mathrm{kg}$ of body weight. The eggs were adhesive and sunk to the bottom and these observations were similar to the result of Mercy et al. (2013). However, hand stripping was not successful in any other treatment. Courtship behaviour could be observed in all the treatments. All the fish, which received $30 \mu \mathrm{gkg}^{-1}$ and $40 \mu \mathrm{gkg}^{-1}$ LHRHa died twelve hours after the hormone administration. Fertilized eggs were spherical and orange-brown with a diameter of $1.6 \pm 0.2$ $\mathrm{mm}$. Eggs hatched within $36 \mathrm{~h}$ after fertilization at $28.8 \pm 03{ }^{\circ} \mathrm{C}$ and, immediately after hatching crawling movements were observed in hatchlings with the yolk sac. Yolk sac was absorbed within 2-3 days. The post-larvae were colourless unlike their adults. According to Mercy et al. (2013) S. denisonii was successfully bred under captivity using Ovaprim hormone at $0.4 \mathrm{~mL}$ per $\mathrm{kg}$ of body weight at $26-27{ }^{\circ} \mathrm{C}$ and at a $\mathrm{pH}$ of 6.5 . Latency period was twelve hours. However in the present study, breeding was successful at $0.5 \mathrm{~mL}$ per $\mathrm{kg}$ of body weight and latency period was nine hours at a water temperature $28.8 \pm 0.3{ }^{\circ} \mathrm{C}$ and $\mathrm{pH}$ $6.4 \pm 0.2$ (Table 3). Achionye et al. (2012) found that increase in Ovaprim dosage resulted in reduced latency period, enhanced the release of more ova and the pressure required for stripping of ova. Moreover, according to his study latency period also reduced with increase in water temperature. 
Table 3. Spawning performance of $S$. denisonii

\begin{tabular}{lc}
\hline Performance of a or mean spawner $^{1}$ & Mean \pm SD \\
\hline Number of eggs laid & $216 \pm 33$ \\
Percentage of fertilized eggs & $65 \pm 7$ \\
Percentage of hatchlings & $52 \pm 8$ \\
Length of a hatchling (mm) & $3.5 \pm 0.2$ \\
Weight of a hatchling (mg) & $0.04 \pm 0.5$ \\
Latency period (h) & 9 \\
Total length: $14.0-14.5 \mathrm{~cm}$, Body weight: $13.0-14 \mathrm{~g}$
\end{tabular}

However, an Ovaprim dosage of $0.4 \mathrm{~mL}$ per kg body weight of fish was not successful in the present study at $28.8 \pm 0.3{ }^{\circ} \mathrm{C}$. Ovaprim and other gonadotrophin hormones are used to induce spawning in numerous fish species in aquaculture (e.g. Rainbow sharks and Red tail black shark E. biclor, freshwater Sharks). Ovaprim has been used successfully in many different families and species of ornamental fish, including members of family Cyprinidae (Koi, goldfish, barbs, freshwater shark), Characidae (pacu), Cobitidae (loaches), different species of catfish (order Siluriformes), and Helostomatidae (kissing gourami), in addition to other fish families and species (Nandeesha et al., 1990).

Present study revealed that LHRHa is not effective for induced breeding of $S$. denisonii. Froud et al. (2010) also found that Barbus sharpeyi could not be successfully induced with LHRHa. Female fish of $S$. denisonii were extremely sensitive to even the smallest stress and died immediately, even though they were matured in captivity (Mercy et al., 2013). This may be the reason for death of fish after administration of high concentrations of LHRHa hormone.

Mercy et al. (2013) indicated that fecundity of S. denissonii ranged from 293 to 967 in length range of 85-122 mm and body weight range of 7-16 g. It was reported that the fecundity of S. denissonii was extremely low when compared with other Cyprinds such as Puntius sarana (Chandrasoma et al., 1994). Radhakishnan and Kurup (2008) indicated that fecundity of $S$. denissonii collected from river Kanjirampuzha and a tributary of river Bharatapuzha was between 74 and 284 respectively. Puntius nigrofasciatus, Puntius cumingi and Puntius pleurotaenia are also known to have a low fecundity ranging between 151 and 638 for fish of length 46-64 mm (Chandrasoma et al., 1994). Present study also agreed with these findings because fecundity of $S$. denissonii had a range of $216 \pm 33$. According to the Mercy et al. (2013a), fertilized eggs had a diameter of $1.184-1.313 \mathrm{~mm}$, but in the present study it was $1.8 \pm 0.3 \mathrm{~mm}$ (Table 2). Mercy et al. (2013) also indicated that the ova diameter of $S$. denissonii ranged from 32 to $288 \mu \mathrm{m}$ in immature stocks, while the mature stock had ova diameter ranging between $928-1440 \mu \mathrm{m}$. These findings also did not agree with the present study findings, because mature eggs had a diameter of $1.6 \pm 0.2 \mathrm{~mm}$.

\section{Effect of initial feed on growth of hatchlings of Sahyadria denissonii}

The results of ANOVA revealed that the growth parameters, length gain and SGR-L of hatchlings were significantly affected by the test diets $(P<0.05)$ over the period of 30 days (Table 5). Of the three tested diets, Artemia nauplii produced significant length gain and SGR-L while it was the lowest for micro-worm and Moina diet $(P<0.05)$. However, Artemia nauplii and micro-worm diets produced higher survival percentage and were not significantly different. Therefore it could infer that even though hatchling fed on micro-worms at initial stage showed comparatively slow growth, the micro-worm could still be used for the rearing 
of hatchlings of S. denissonii. Low growth performances and survival percentage for Moina diet may be partly due to the size of the diet not compatible with mouth size of hatchlings.

Table 5. Growth performances of Sahyadria denissonii

\begin{tabular}{|c|c|c|c|}
\hline & \multicolumn{2}{|c|}{$\operatorname{Mean}^{1} \pm \mathrm{SE}$} & \multirow[b]{2}{*}{ Moina } \\
\hline & Artemia & Micro-worm & \\
\hline Mean $\quad$ Initial length & $3.5^{\mathrm{a}} 0.2$ & $3.5^{\mathrm{a}} \pm 0.2$ & $3.5^{\mathrm{a}} \pm 0.2$ \\
\hline$(\mathrm{mm})$ & $15.0^{\mathrm{a}} \pm 0.2$ & $13.9^{\mathrm{b}} \pm 0.48$ & $9.8^{\mathrm{c}} \pm 0.45$ \\
\hline Mean Final length (mm) & $11.5^{\mathrm{a}} \pm 0.1$ & $10.4^{\mathrm{b}} \pm 0.28$ & $6.3^{c} \pm 0.26$ \\
\hline Mean Length gain (mm) & $3.01^{\mathrm{a}} \pm 0.14$ & $2.73^{\mathrm{b}} \pm 0.13$ & $2.17^{\mathrm{c}} \pm 0.10$ \\
\hline SGR-L & 95 & 93 & 30 \\
\hline Survival \% & & & \\
\hline
\end{tabular}

According to the Sundarabarathy et al. (2004), Artemia nauplii and micro-worm could be used as the starter feed for Puntius titteya. Present study findings also agreed with these findings.

\section{CONCLUSIONS}

Captive breeding of $S$. denissonii can be performed successfully using a single dose of synthetic hormone Ovaprim at $0.5 \mathrm{~mL} / \mathrm{kg}$ of body weight of female and a half the dose for the male. Latency period was found to be $9 \mathrm{~h}$ from the time of hormone injection. $S$. denissonii is extremely sensitive to the high doses of LHRHa hormone and leads them to death. As for most of fish species, Artemia nauplii and Micro-worm could be given as the starter feed for S. denissonii post larvae.

\section{REFERENCES}

Achionye-nzeh, C.G. and Obaroh, I.S.R.A.E.L. (2012). Ovaprim doses effects on eggs of African Mudfish (Clarias gariepinus). Int. J. Life Sci. Biotechnol. Pharma. Res. 2, 6-9.

Chandrasoma, J., Chin. H.C. and Amandakoon, H.P. (1994). Reproductive biology and breeding of Cuming's barb (Puntius cumingii Gunther). J. Appl. Ichthyol. 10(2-3), 209-214.

Kahkesh, F.B., Feshalami, M.Y., Amiri, F. and Nickpey, M. (2010). Effect of ovaprim, ovatide, HCG, LHRH-A2, LHRHA2+ CPE and carp pituitary in Benni (Barbus sharpeyi) artificial breeding. Glob. Vet. 5(4), 209-214.

Manoj, C.K., Nair, C.M., Salin, K.R. and Pillai, D. (2010). Captive breeding and embryonic development of puntius denissonii, an endemic ornamental fish in the rivers of the Western Ghats, Kerala, India. Fishing Chimes, 29(12), 18-21.

Mercy, T.V.A., Malika, V. and Sajan, S. (2013). Reproductive biology of Puntius denisonii (day 1865) an endemic ornamental cyprinids of the Western Ghats of India. Indian J. Fish. 60, 73-78.

Mercy T.V.A., Malika, V. and Sajan, S. (2013a). Use of Tricainemethanesulfonate (MS 222) to induce anaesthesia in Puntius denisonii (Day 1865) (Teleostei: Cypriniformes: 
Cyprinidae) an endangered Barb of the Western Ghats hotspot. India J.Threat. Taxa. 5(9), 4414-4419.

Mittal, R. ( 2009). Business unusual: conserving Miss Keral. Aquarama Magazine 12, 7-9.

Nandeesha, M.C., Rao, K.G., Jayanna, R., Oarker, N.C., Varghese, T.J., Keshvnath, P. and Shetty, H.P.C. (1990). Induced spawning of Indian major carps through single application of ovaprim. pp 581-585. In: Hirani, R. and Hanyu, I. (Eds.), Proceedings of the Second Asian Fisheries Forum, Asian Fisheries Society, Manila, Philippines.

Raghavan, R., Dahanukar, N., Tlusty, M., Rhyne, A., Kumar, K.K., Molur, S. and Rosser, A. (2013). Uncovering an obscure trade: threatened freshwater fishes and the aquarium markets. Biol. Conserv. 164, 158-169.

Raghavan, R., Prasad, G., Pereira, B., Anvar Ali, P. H. and Sujarittanonta, L. (2009). 'Damsel in distress'-The tale of Miss Kerala, Puntius denisonii (Day), an endemic and endangered cyprinid of the Western Ghats biodiversity hotspot (South India). Aquat. Conserv. 19(1), 67-74.

Radhakrishnan, K.V. and Kurup, B.M. (2005). Aspects of life history traits of Puntius denisonii (Day), an endemic and threatened ornamental fish of Kerala. In Sustain Fish 2005 International Symposium on Sustainability of Fish Production Systems and Appropriate Technologies for Utilization. Cochin University of Science and Technology pp. 16-18.

Sekharan, M. and Ramachndran, A. (2006). Market preferred indigenous ornamental fishes of Kerala. OFI Journal 52, 20-21.

Sundarabarathy, T.V., Edirisinghe, U. and Dematawewa, M.B. (2004). Captive breeding and rearing of fry and Juveniles of Cherry Barb (Puntius titteya Deraniyagala), a highly threatened endemic fish species in Sri Lanka. Trop. Agric. Res. 16, 137-149. 